\title{
PLEISTOCENE PRAIRIE DOG IN SOUTH-CENTRAL ALBERTA
}

\author{
by JOHN E. STORER*
}

On 30 June, 1975, Linda J. Strong and I collected a well-preserved right mandible of a prairie dog (Provincial Museum of Alberta registration number P75.7.1) from the Hand Hills Formation south of Delia, Alberta. The jaw contains the lower cheek-teeth $\left(\mathrm{P}_{4}\right.$ to $\mathrm{M}_{3}$ : Length of cheek-tooth series $14.1 \mathrm{~mm}$ ), and was discovered in bulldozed material of a gravel pit (Lsd. 16 Sec. 16 T30 R 17 W4).

The specimen is not distinguishable from the living black-tailed prairie dog (Cynomys ludovicianus), as indicated by comparison with modern specimens in the University of Alberta and Provincial Museum of Alberta.

Cynomys ludovicianus was not present in the previously reported Pleistocene fauna from the same locality. ${ }^{3}{ }^{4}$ The fossil record of $C$. ludovicianus spans Kansan to Recent time, ${ }^{1}$ the addition of this species does not allow more precise assignment of age to the Hand Hills Pleistocene fauna, which was estimated to be Irvingtonian (late Kansan) or younger. ${ }^{34}$

The Hand Hills lie about $225 \mathrm{mi}$. $(410 \mathrm{~km})$ northwest of the nearest modern occurrence of black-tailed prairie dogs, near Val Marie, Saskatchewan. As noted by Stalker and Churcher for two faunas near

*Provincial Museum of Alberta, Edmonton, Alberta.

T5N $0 M 6$
Medicine Hat, the presence of Cynomys indicates that the Pleistocene fauna of the Hand Hills may have lived in a climate somewhat warmer and drier than prevails there today. ${ }^{2}$

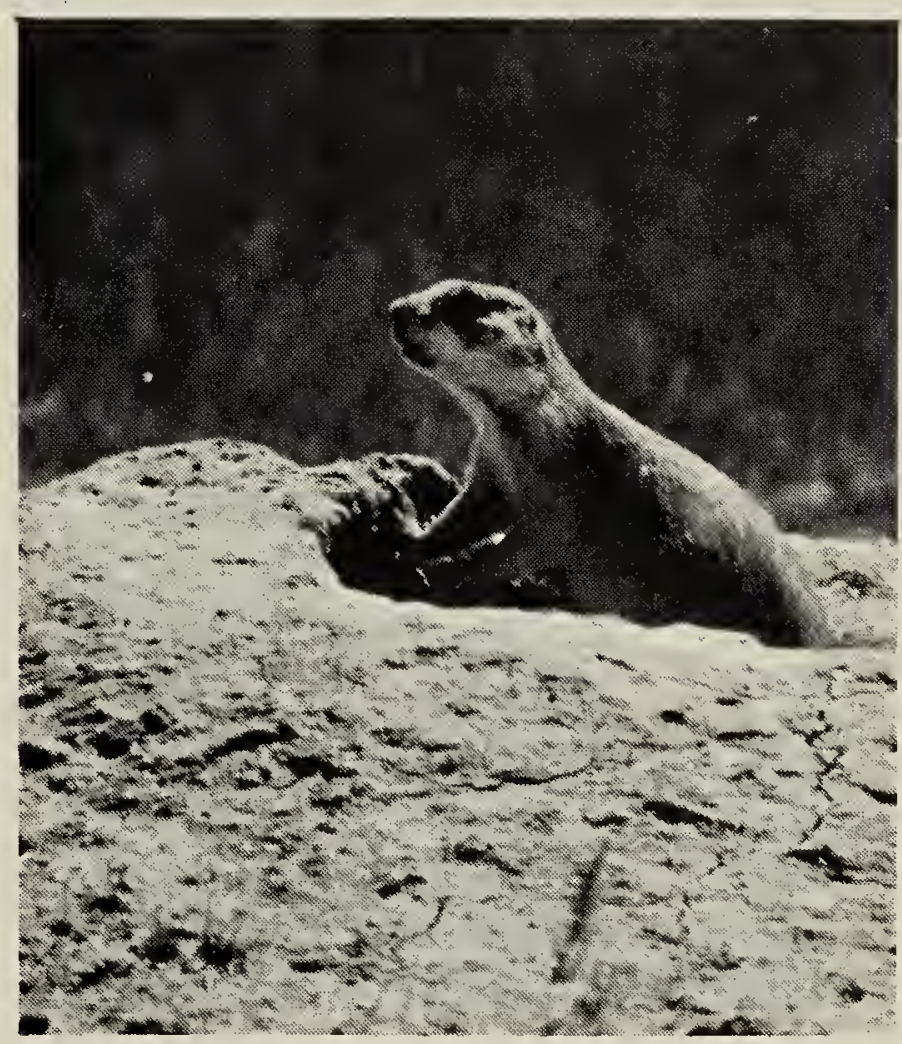

Black-tailed Prairie Dog.

G. W. Seib

'HIBBARD, C. W. 1970. Pleistocene mammalian local faunas from the Great Plains and Central Lowland provinces of the United States. In Dort, and Jones, J. K. (eds.). Pleistocene and Recent environments of the Central Great Plains. Dept. Geol., Univ. Kansas, Spec. Publ. 3. University Press of Kansas, Lawrence/Manhattan/Wichita. p. 395-433.

"STALKER A. MACS., and C. S. CHURCHER 1970. Deposits near. Medicine Hat, Alberta, Canada. (Chart). Surveys and Mapping Branch, Geol. Surv. Can.

"STORER, J. E. 1972. Mammals of the Hand Hills Formation of southern Alberta: preliminary faunal list. Blue Jay 30: 119-120.

${ }^{4}$ STORER, J. E. 1975 (in press). Mammals of the Hand Hills Formation, southern Alberta. Life Sci. Contr., R. Ont. Mus. 